\title{
Research on Family Virtue Education of College Students Based on Three-Dimensional System
}

\author{
Yunping $\mathrm{Zhu}^{1, *}$ \\ ${ }^{1}$ School of Marxism, Quanzhou Normal University, Quanzhou, Fujian 362000, China \\ *Corresponding author. Email: zhu65@163.com
}

\begin{abstract}
Family virtues have an important impact on social morality. Although college students have higher moral quality, there are also some problems in their family virtues, such as unequal respect for the old and love for the young, casual and thoughtless view of love and marriage, blind and impulsive consumption, and indifferent concept of family love. To educate college students on family virtues is helpful to improve college students' moral quality, to enrich and inherit fine family traditions, and to build a harmonious society. In order to educate college students about family virtues, colleges and universities should adopt the path of education under the three-dimensional system of university, student, and campus environment. That is, colleges and universities should establish a family virtues education system, and college students should take the initiative to integrate into the family virtues education and create a family virtues education atmosphere on campus.
\end{abstract}

Keywords: universities, college students, family virtue education

\section{INTRODUCTION}

Family virtue is the highest level norm in the category of family morality. "Family virtues include respecting the old and caring for the young, equality between men and women, harmony between husband and wife, diligence and thrift, and unity among neighbors" [1]. As the cell of the society, the family is the starting point of personal growth and the place to receive the enlightenment of moral education. The effect of family virtue education affects the cultivation of every member's moral quality, and also affects the progress of personal "private morality". College students are the main force of the future national construction and the leading group of the future social moral construction. College is a crucial period for them to transition from school to society. At this stage, their family ethics have an important impact on their future moral concepts. This paper intends to study the path of family virtues education for contemporary college students, so as to lay the foundation for them to become qualified talents in the future.

\section{THE PROBLEMS EXISTING IN COLLEGE STUDENTS' VIEW OF FAMILY VIRTUES}

On the whole, the mainstream of the current college students' family ethics is healthy, but a small number of college students are also affected by the negative family ethics abroad. Through the field interviews with some college students in China, combined with the analysis of literature review, network data and other means, the problems existing in the concept of family virtue among contemporary college students are as follows:

\section{A. Respecting the aged and caring for the young are not equal}

Respecting the aged and caring for the young is the first norm of family virtues. Parents and children are the basic relationship of the family. Parents love children, children filial piety parents, elders care for the younger generation, the younger generation respect the elder, these requirements of respect for the elderly is not only one of the core of the Chinese traditional family virtues, but also family members should abide by the norms and norms. According to the survey, half of the college students said that at home, they seldom help their parents do some housework within their power, and a few college students can't understand their parents' hardships. While parents' selfless love for their children is more common, and even a few of them have reached doting. In the current family relationship, most college students are loved by their grandparents and parents. The virtue of "caring for the young" family is better. However, "respecting for the elderly" is relatively unequal. Some college students are accustomed to regard themselves as the sun and blindly demand from their parents and elders, and lack of the sense of "respecting the elderly" that they are responsible for their families and respect their elders. The phenomenon of "insufficient respect for the old and excessive love for the young" appeared in family life. 


\section{B. The casual and thoughtless view of marriage and love}

Marital relationship is the origin of family relationship, and marital relationship directly affects the stability of family relationship. College students are facing the stage of marriage, which is very important to form a healthy view of love and marriage. According to the survey, contemporary college students' views on marriage and love are often described as "willful", "arbitrary" and "thoughtless", which is admittedly exaggerated, but these statements do exist to some extent. For example, some college students are individualistic and lack the consciousness of friendly coexistence and equal respect for others. After falling in love, they put their own capricious on the other side, unilaterally indulge their own emotional capricious, shackle or force the other side to their obedience, it is difficult to achieve the equal respect for the lovers, treat love and marriage as a game, casual, reckless abandon. Influenced by the negative effects of market economy, some college students' views on marriage and love are not based on sincere feelings but material conditions, and are not based on common pursuit but on utilitarianism, resulting in the lack of specificity and stability of love and marriage.

\section{The consumption concept of blind impulse}

According to the survey, a small number of college students believe that people should enjoy themselves in time, and life is consumption, so they ignore their economic ability to excessive consumption, even blindly pursue luxury consumption. The pursuit of brand far more than the actual use value of goods, expect to improve their position by the use of brand name. What's more, they pursue the so-called fashion, trend and other consumption, blindly and impulsively consume, compare with each other and even borrow money for it. For example, in 2019, "the recent consumption survey of college students released by relevant institutions shows that compared with the previous" post-80s "and" post-90s ", online payment and excessive consumption of college students are more common today... Experts point out that young people are prone to impulsive and irrational consumption behaviors due to physiological and psychological factors "[2].Although there is no exact data on the consumption of college students in recent years, "according to Alipay's consumption data, the consumption per capita of 10 million college students in 4000 universities across the country has exceeded 40 thousand yuan, of which the brand clothing, beauty and other products occupy the forefront, which undoubtedly brings hidden trouble to college students with unstable economic income [3].

\section{Indifferent concept of family}

Attaching importance to family affection is an important part of family virtues. Only when college students know how to love their relatives can they love others, the society and the country. At present, some college students are indifferent to the concept of family love. For example, they are more and more indifferent to their relatives who care about them and have less and less communication with them. Especially for parents, the formation of blindly ask for material and money habit, less the initiative, active care and understanding of parents. They are selfish and callous and don't contact and communicate with their relatives for a long time, even when they are in difficulties and need help. They become angry and even extreme when their relatives do not meet their demands. Some college students lack the consciousness of sharing the burden for family members, even in extreme cases. For example, the Internet has repeatedly revealed that some college students strongly oppose their parents to have a second child, detest or even hate the phenomenon of their own siblings. In the minds of some college students, the concept of kinship began to disappear, and the relationship with relatives became more and more estranged.

\section{THE IMPORTANCE OF FAMILY VIRTUE EDUCATION FOR COLLEGE STUDENTS}

Our country has always attached great importance to family virtues. In the implementation outline of citizen moral construction issued by the state council in 2001 , it was pointed out that "we should vigorously advocate family virtues with respecting the aged and caring for the young, equality between men and women, harmony between husband and wife, diligence and frugality, and neighborhood solidarity as the main contents" [4]. At present, it is very important to educate college students on family virtues, which is mainly reflected in the following aspects:

\section{A. It helps to improve the moral quality of college students}

Good moral character is the premise for college students to become the pillar of future national construction, which affects the level of moral, intellectual and physical comprehensive quality of college students. Family virtue education plays an important role in forming college students' good moral character. Through the education of family virtues for college students, they can form the concept of family virtues and have a deep sense of family and country, so that they can realize their due responsibilities as family members, and realize their due responsibilities as social members and national citizens. In addition, family virtue education can make college students deeply understand the deepest meaning of "family love" in all 
human love: as children, we should honor our parents, and as the junior, we should respect our elders. If college students understand the responsibilities of various roles as a family, they can take on the responsibilities of future life during college, such as studying hard, accumulating knowledge, mastering professional skills, etc. If you have a good family virtue, you will be able to become the moral talents the country needs in the future. If you are willing to serve your family, you will be willing to serve your country. The country is a collection of tens of thousands of families. As a part of the country, the family and the country cannot be separated.

\section{B. It is conducive to the enrichment and inheritance of fine family traditions}

Family style is the core value of family spirit and the fashion concept passed down from generation to generation. The gathering of countless family traditions has become the cornerstone of a nation's spirit. To educate college students on family virtues can contribute to the inheritance of fine family traditions. Family virtue education can set the family style as one of the embedded points, so that the content of good family style can be spread and inherited. In addition, although college students are still studying in school, they will eventually go into the society and form families. That is, in the whole family, to assume the family style content construction of the link between the status, not only the inheritance of excellent family style content inheritance, but also shoulder the responsibility of family virtues continuously input fresh content. College students can inject family virtues into their family building, which will be beneficial to their own family good family style. Thirdly, in the discussion of family virtue education, college students can communicate with each other in the discussion. In such a teaching process, they can spread the good family tradition, which is the edification of excellent family traditions for all college students, thus contributing to the formation of a good family traditions construction environment in the whole school.

\section{It is conducive to the construction of a harmonious society}

As the cell of the society, the family can be harmonious so that the social individuals represented by family members can effectively release the pressure from the society and make certain contributions to the social harmony. And family harmony needs family virtue education. If the family virtue education is carried out in colleges and universities so that college students know how to abide by family virtue, they can think and implement how to do their best for family harmony. As far as college students are concerned, they will grow into the main force of social development and establish their own families as members of the future society. If colleges and universities can carry out effective family virtue education for college students, then college students can possess the beauty of harmonious families. On the one hand, they can promote the realization of social harmony; on the other hand, they can promote a virtuous circle with the continuous continuation of family and society, so that family harmony can continuously strengthen the support of social harmony. As far as college students themselves are concerned, having received the family virtue education, they can also strengthen their family responsibility mission and social mission, and become good sons and daughters, good brothers and sisters, good parents and other family roles and become a solid bridge between family members, family affection, neighbors and the society. In this way, the family virtues education of college students can not only bring harmony to their family life, but also provide the foundation for the construction of a harmonious society.

\section{SUGGESTIONS ON THE PATH OF FAMILY VIRTUE EDUCATION FOR COLLEGE STUDENTS}

To carry out family virtue education for college students, we should adopt the education path under the three-dimensional system of university-student-campus environment, so that every time and space segment of each college student can be interconnected. Only by making college students feel the all-round family virtue education can the teaching effect be improved continuously. This is reflected in the following aspects:

\section{A. Colleges and universities should establish a family virtue education system}

Colleges and universities should establish a scientific system of family virtue education as the leading way of family virtue education for college students. Firstly, subjectively, colleges and universities should realize that family virtue education is a necessary part of cultivating qualified college students. University grade for freshman year to senior year at different stages of psychological characteristics, based on the family ethics of Marxism, socialist core values, for leading, choice conforms to the content of the new era, the current situation of family virtues and point of view, combined with the contemporary college students psychological characteristics, adopt the different education method, to determine the family virtue education in college moral education system. Secondly, universities should choose or compile appropriate teaching materials and tutorial materials. Although there are a lot of family moral education textbooks or reading books on the market, there is no set of standard textbooks that can be used for college students' family moral education. Colleges and universities should organize relevant teachers on campus, or in conjunction with teachers in related fields of other colleges and universities, establish relevant research organizations or 
institutions, and jointly compile or select textbooks and counseling materials in line with the family virtue education of college students. Thirdly, colleges and universities should set up family virtue education courses and set up family virtue education contents in relevant courses. For example, Chinese traditional family training and family rules courses are offered to learn the excellent Chinese traditional family training and family rules family education moral courses; For example, in some theoretical courses, marriage and love, parenting, Thanksgiving related content can be set up to exercise college students' family life skills; For example, in some practical training courses, homemaking related content can be set separately to train college students' family life skills. Besides the theory teaching, some short videos close to family life and students' discussion can be interspersed to enhance the vividness and appeal of family virtue education.

\section{B. College students should take the initiative to integrate into family virtue education}

Only by taking the initiative to integrate into the family moral education can college students improve their learning effect. This is above all subjectively raises the importance degree. Family virtues are the moral means to restrain the behavior norms of family members. Throughout the ages, most countries have encouraged the inheritance of family virtues. Only by attaching importance to family virtues can college students master the knowledge of family virtues and apply it to their future life. Family virtue is also one of the internal driving forces, which can provide guidance for the future family behavior of college students. The second is to master the knowledge of family virtues in theoretical learning. College students should take advantage of class time of concentration and fragmentation of the time after class, study hard and master relevant knowledge, family virtues of important knowledge points and key points of careful reading and reflection, and the difficulties of knowledge in the study hard hammering out to comprehend its connotation, and combined with their excellent family virtues or outside case, deepen the understanding of the family virtues knowledge level. The third is the use of social practice to deepen the theoretical knowledge of family virtues. To master the theoretical knowledge of family virtues is to keep the acquired knowledge in the brain, and to strengthen the individual's understanding through practice, so as to test it and use it for us. Therefore, college students actively take advantage of various opportunities to participate in social practice, such as participating in a variety of volunteer activities related to family life, taking part in some community activities and voluntary labor in the community near the school, and actively communicating with family members and neighbors about the theme of family virtues when they go home during the holidays, supplemented by relevant actions. In the process of social practice, college students should constantly deepen their understanding of family virtues and enrich the extension of family virtues knowledge they have mastered.

\section{To create a college campus family virtue education atmosphere}

Campus is a place for college students to study and live, and by virtue of the school environment to create a family virtue education atmosphere, can effectively improve the effectiveness of teaching. Campus atmosphere is a group educational atmosphere which contains spiritual atmosphere and cultural environment by virtue of the geographical place of university campus. To create an atmosphere of family virtue education on campus is to contextualize the education of family virtue. Situational education can make use of the learning and living environment of college students to exert a subtle influence on students, so that they can naturally enhance the awareness of family virtues. Such as increases or interspersed some stories about family virtues and case in the campus broadcast, organize some activities such as knowledge contest, essay contest, class and college debate contest with the theme of family virtue, and at the right time, some festivals, such as father's day and mother's day, are used to promote family virtues, and some columns related to family virtues should be set up in school publicity window, school publicity publication, class blackboard, etc. According to the emotional characteristics of college students who participate in voluntary organizations due to their personal preference and pleasure, schools can establish some associations of family virtue education, and organize college students to regularly carry out association activities related to the theme with the help of these associations, so as to infect each other. In view of the characteristics of college students' extensive use of new media, various new media can be widely used in the school, college public accounts such as Microblog, WeChat, QQ, etc., and set up corresponding sections or columns to attract college students' active attention and participation. In addition, colleges and universities can make use of dormitory life to improve students' ability of family life, such as the development of dormitory living environment.

\section{CONCLUSION}

The study of college students in college is of great enlightenment significance to their whole life stage, and the family virtue education of college students also plays a guiding role in the harmony of their family life. Therefore, the construction of the university - college students - campus environment three maintenance system of education system, can greatly improve the teaching effect, which is a full range of college students to enhance the family virtue quality of powerful measures. 


\section{References}

[1] Book Compilation Group. Ideological and Moral Cultivation and Legal Basis [M]. Beijing: Higher Education Press,2018:123

[2] Wang Junling. When You Go to College, Where Do Post-2000s College Students Spend Their Money? [N]. People's Daily (Overseas edition),March26,2019(06)

[3] Ma Yuping. Media Survey: The Average Consumption of College Students in 2016 Reached 40,000 [N]. China Youth Daily January $4,2017(02)$

[4] Book Compilation Group. [M]. Beijing: Xinhua Press, 2001:9

[5] Compilation Team of This Book. Ideological and Moral Cultivation and Legal Basis [M]. Beijing: Higher Education Press, 018:97.

[6] Xi Jinping. Win the Battle and Build a Well-off Society in an All-Round-Way - Win the Great Victory of Socialism with China's Characteristics in the New Era [M]. Beijing: People's Publishing House, 2017: 41. 